Chirurgia (2018) 113: 455-463

No. 4, July - August

Copyright $\odot$ Celsius

http://dx.doi.org/10.21614/chirurgia.113.4.455

\title{
Surgical Stress Response and Enhanced Recovery after Laparoscopic Surgery - A systematic review
}

\author{
Jacopo Crippa', Gulio M. Mari², Angelo Miranda'2, Andrea T.M. Costanzi², Dario Maggioni² \\ ${ }^{1}$ General Surgery Residency Program, University of Milan, Italy \\ ${ }^{2}$ ASST MONZA, Desio Hospital, Laparoscopic and Oncological General Surgery Department, Italy
}

Corresponding author: Jacopo Crippa, M.D.

Resident in General Surgery

E-mail: jacopocrippamd@gmail.com

Received: 25.04 .2018

Accepted: 10.06 .2018

\section{Rezumat}

Răspunsul la stresul chirurgical și îmbunătățirea recuperării după interventia chirurgicală laparoscopică - O analiză sistematică

Contextul: Programul îmbunătățit de recuperare (Enhanced Recovery Program ERP) este un protocol multimodal perioperator. Fezabilitatea şi beneficiile rezultatelor sale pe termen scurt au fost raportate la scară largă. Îmbunătățirile descrise, ca de exemplu durată mai mică a spitalizării şi reluarea timpurie a funcțiilor corpului, reprezintă consecința unui răspuns atenuat la stresul chirurgical. Atunci când răspunsul este necontrolat, acesta poate duce la complicații postoperatorii şi la rezultate slabe pe termen lung. Răspunsul la stresul chirurgical poate fi monitorizat cu uşurință prin analiza mediatorilor din fluxul sanguin. Dovezile actuale nu au relevat până acum dacă programul de recuperare permite măsurarea reducerii stresului chirurgical. În cadrul acestui studiu, am căutat articole ştiințifice care să investigheze răspunsul la stresul chirurgical şi programul de recuperare aplicat în urma procedurilor minim-invazive de elecție, pentru a înțelege mai bine nivelul evidenței privind eficiența programului de recuperare.

Material şi metodă: $\mathrm{O}$ analiză sistematică a literaturii a fost efectuată folosind baze de date PubMed, Cochrane, EMBASE şi Google Scholar, urmând liniile directoare PRISMA (Preferred Reporting Items for Systematic Review and Meta-analysis). Studiile includ analiza răspunsului la stresul chirurgical şi programul de recuperare aplicat pacienților care au suferit intervenții chirurgicale laparoscopice în diferite specialități. Au fost incluse opt studii, cu un total de 632 de pacienți.

Rezultate: Cei trei paşi ai programului de recuperare - endocrin, 
inflamator şi nutrițional - au fost raportați în aceste studii, inclusiv în articolul prezent. Rezultatele nu au arătat diferențe în faza endocrină, dar au relevat un răspuns inflamator atenuat la pacienții care au urmat programul de recuperare atunci când Interleukina- 6 şi Proteina $C$ reactivă au fost dozate. Starea nutrițională a fost de asemenea menținută, albumina, prealbumina şi transferina au avut valori mai bune la aceşti pacienți.

Concluzii: Programul de recuperare aplicat în urma interventiilor chirurgicale laparoscopice are un rol în reducerea stresului chirurgical. Acest lucru poate fi demonstrat prin analiza mediatorilor ca de exemplu Interleukina-6, Proteina $\mathrm{C}$ reactivă şi markerii nutriționali.

Cuvinte cheie: recuperare îmbunătățită după chirurgie, chirurgie laparoscopică, răspuns la stres, acțiune rapidă

\begin{abstract}
Background: Enhanced Recovery Program (ERP) is a multimodal perioperative protocol. Its feasibility and benefits on short term outcomes have been widely reported. These well described improvements, like shorter length of stay and early resumption of body's functions, represent the consequence of an attenuated surgical stress response (SSR). When this response is uncontrolled, it leads to postoperative complications and poor long-term outcomes. SSR can be easily monitored through the analyses of mediators in the bloodstream. Available evidences do not achieve to tell if ERP allows a measurable surgical stress reduction. In this review, we searched for papers investigating the surgical stress response and ERP applied to elective mini-invasive procedures, in order to better understand the level of evidence regarding the effectiveness of ERP in minimizing the surgical stress response.

Materials and Methods: A systematic review of published literature was performed using PubMed, Cochrane, EMBASE and Google Scholar database, following the Preferred Reporting Items for Systematic Review and Meta-analysis (PRISMA) guidelines. Included studies concerned SSR analysis in ERP patients undergoing laparoscopic surgery through different surgical specialties. Eight studies with a total of 632 patients were included.

Results: The three steps of SSR, endocrine, inflammatory and nutritional were all reported in the papers included in this review. Results showed no powerful evidence of difference in endocrine phase while an attenuated inflammatory response was reported for ERP patients when Interleukin-6 (IL-6) and C Reactive Protein (CRP) were dosed. Nutritional status was also preserved as albumin, pre-albumin and transferrin had better values in these patients.

Conclusions: ERP applied to different types of laparoscopic surgery has a role in reducing SSR. This can be shown by the analysis of mediators such as IL-6, CRP and nutritional markers.
\end{abstract}

Key words: enhanced recovery after surgery, laparoscopic surgery, stress response, fast-track

\section{Introduction}

Enhanced recovery program (ERP) represents a milestone in surgical care. The feasibility of ERP and its benefit on short term outcomes have been widely reported. Enhanced Recovery has been strongly applied to colorectal surgery $(1,2)$. Nowadays, guidelines regarding gastric (3), pancreatic (4), gynecology (5), bariatric (6), hepatic (7) and urologic (8) surgery are available. In some countries, ERP has become mandatory for patients undergoing colorectal surgery (9).

Fast Track protocols were first developed to ensure a faster recovery after surgery. Moving from a "faster" to an "enhanced" concept has been a paradigm shift: modulating the Surgical Stress Response (SSR) has become the core of ERP. The mechanisms and organic systems 
involved in the stress response have been studied for years. Earlier published papers described the pathophysiology underneath these changes through the analysis of stress markers (10). Surgery causes a predictable reaction involving the metabolic, neuroendocrine and immunological systems (11). The hormones response raises catecholamine levels and patients develop tachycardia, hypertension and tachypnea. The cellular reaction leads to the synthesis of pro-inflammatory cytokines like Tumor Necrosis Factor alpha, C-reactive protein (CRP), Interleukin (IL)-1, IL-6 and IL-8. Postoperative IL-6 and CRP are useful markers to describe the magnitude of surgical injury (12).

Well reported improvements brought by ERP, like shorter recovery and early resumption of physiological functions,represent a consequence of an attenuated SSR, while an uncontrolled response is associated with post-operative complications and poor long-term outcomes (13). Furthermore, SSR can be responsible for an uncontrolled inflammatory syndrome that leads to immunodepression.

The body reaction to trauma can be easily monitored through the analyses of mediators in the bloodstream. The impact of ERP on stress response is measurable as well, but we are far from understanding the actual reduction of stress that ERP allows. What seems to be clear is that laparoscopic surgery is the only ERP item that independently reduces surgical stress (14). Available evidences do not achieve to tell if ERP in a laparoscopic setting allows a measurable surgical stress reduction.

In this review, we searched for papers investigating SSR and ERP applied to elective miniinvasive procedures through the analysis of mediators, in order to better understand the level of evidence regarding the effectiveness of ERP in minimizing the surgical stress response.

\section{Material and Methods}

\section{Selection of Studies}

The review has been registered in PROSPERO
(International prospective register of systematic reviews, http://www.crd.york.ac.uk/PROSPERO /searchadvanced.php) with the registration number CRD42017071851, and was performed following the Preferred Reporting Items for Systematic Review and Meta-analysis (PRISMA) guidelines (15). The following databases were searched to obtain a list of studies: PubMed, Cochrane Database, EMBASE and Google Scholar. Additional records were identified manually by two specific authors. The following search criteria were used for each database: "(fast track) AND ((surgical stress) OR (immune function))" or "(enhanced recovery after surgery) AND ((surgical stress) OR (immune function))" or "(ERP) AND ((surgical stress) OR (immune function))". Studies were limited to English language and the last search date was June $1^{\text {st }}$, 2017. Data from identified studies were extracted independently by 2 authors (JC and GM) using a standardized format. References of the included studies were evaluated to identify other potential trials.

\section{Inclusion and exclusion criteria}

We included in this systematic review fulllength articles that met the following criteria:

1. Trials regarding patients undergoing mini-invasive surgery;

2. Trial regarding patients treated within an Enhanced Recovery Pathway (At least 7 items distinct from traditional care);

3. Trials analyzing the surgical stress response in terms of immunity function, nutritional function or surgical stress indexes;

4. Studies design as: Randomized, casecontrol.

Studies with any of the following feature were excluded:

1. Published in languages other than English;

2. Trials regarding patients undergoing open surgery only or emergency surgery;

3. Studies where differences between Enhanced protocol and a Standard care protocol was not an end-point. 


\section{Quality and Risk of Bias Assessment}

Two reviewers (JC, GM) independently assessed the quality and risk of bias of the papers selected using SIGN levels of evidence and grades of recommendation. (http://www.sign.ac.uk/).

\section{Results}

Eight Studies were selected to meet the inclusion and exclusion criteria as described in Fig. 1.

The reviewers identified 865 studies as potentially relevant. Screening for abstract led to sixty-eight full text papers assessed for eligibility. Sixty articles were excluded for not meeting the inclusion criteria.

Seven papers were randomized controlled trials (RCTs) and one was a case control study. Four papers involved patients undergoing open surgery and laparoscopic surgery (16-19). Patients undergoing laparotomic surgery in these papers were excluded from the analysis.

The total number of patients included in this review was 632 , all of them undergoing laparoscopic surgery, 312 treated within an ERP and 320 with a traditional care. All the papers included in the review are described in Table 1.

Quality and risk of bias assessment is reported in Table 2: one out of eight papers was a RCT rated as high quality (level of evidence $1++)$. Six out of eight were RCTs rated as acceptable (level of evidence 1+). One out of eight was a case-control study rated as acceptable (level of evidence $2+$ ).

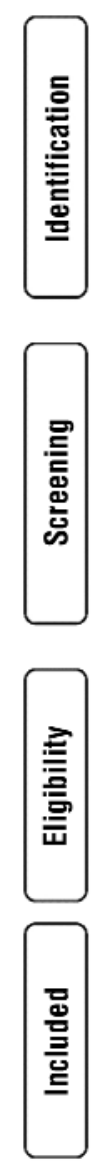

\section{Records identified through database searching} $(n=802)$
Additional records identified

through other sources $(n=63)$

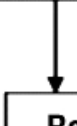

Records after duplicates removed $(n=631)$

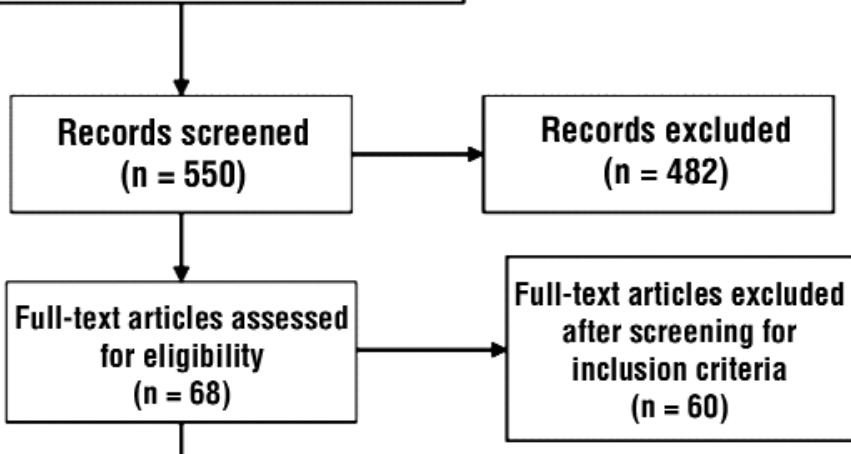

Studies included in qualitative synthesis $(\mathrm{n}=8)$

Figure 1. PRISMA flow chart 


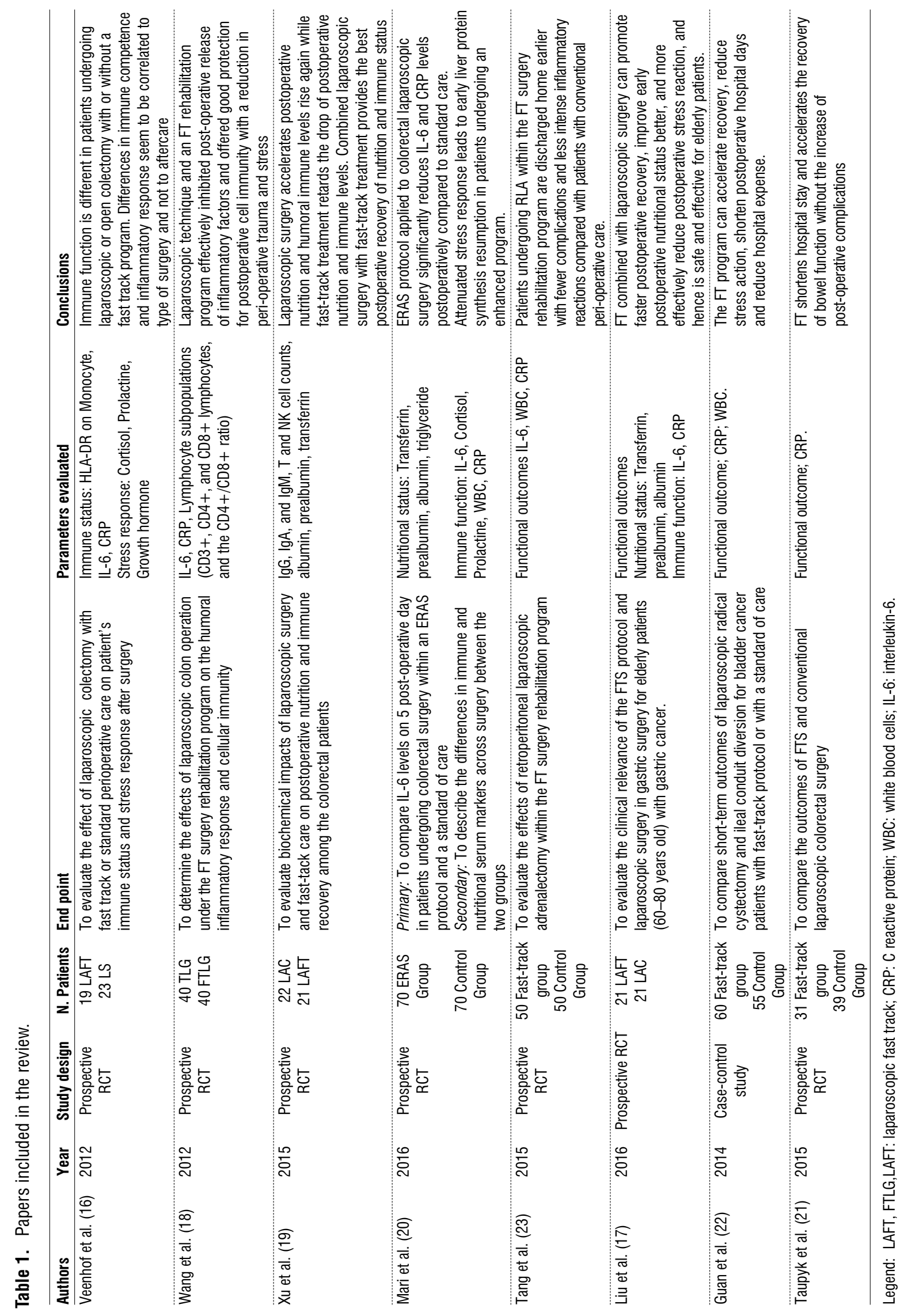


Table 2. Description: Quality and risk of bias assessment

\begin{tabular}{lcccc}
\hline Authors & Year & Study design & Overall assessment of the study & Level of evidence \\
\hline Veenhof et al. (16) & 2012 & Prospective RCT & Acceptable & $1+$ \\
\hline Wang et al. (18) & 2012 & Prospective RCT & Acceptable & $1+$ \\
\hline Xu et al.(19) & 2015 & Prospective RCT & Acceptable & $1+$ \\
\hline Mari et al. (20) & 2016 & Prospective RCT & High quality & $1++$ \\
\hline Tang et al. (23) & 2015 & Prospective RCT & Acceptable & $1+$ \\
\hline Liu et al. (17) & 2016 & Prospective RCT & Acceptable & $1+$ \\
\hline Guan et al. (22) & 2014 & Case-control study & Acceptable & $2+$ \\
\hline Taupyk et al. (21) & 2015 & Prospective RCT & Acceptable & $1+$ \\
\hline
\end{tabular}

\section{Analysis of Findings}

Five studies regarded patients undergoing colorectal surgery $(16,18-21)$, one study gastric surgery (17), one study cystectomy (22) and one study retroperitoneal adrenalectomy (23).

Three papers reported nutritional and immune function evaluation $(17,19,20)$, two papers compared the differences in stress hormones response $(16,20)$. Three papers investigated surgical impact in terms of humoral response measuring HLA-DR expression on monocyte, Immunoglobulin (Ig) or lymphocyte subpopulations $(16,18,19)$. Five studies used IL-6 as a marker of surgical stress (16-18, 20, 23). Guan et al. (22) dosed CRP and White blood cells count (WBC), Taupyk et al. (21) only CRP.

The range of sampling time to evaluate stress and nutritional markers went from 2 hours after surgery till post-operative day (POD) 7.

The majority of papers showed better surgical stress indexes for ERP group. Many authors used
IL-6 as a marker of stress response. The analyses showed better values immediately after surgery and lasting within days. CRP is another investigated parameter and it is commonly used in clinical practice. The majority of the papers in this review showed less inflammatory insult in term of CRP in patients treated with ERP. CRP showed the same pattern as IL-6, being lower as close as 2 hours after surgery (23) till POD 7 (17, 22 ). Only two authors investigated the stress response dosing pituitary and adrenal hormones $(16,20)$. Table 3 reports statistically significant results.

Xu et al. (19) described a series of 43 laparoscopic cases undergoing colon surgery. They reported no difference in term of Immunoglobulin (Ig), T cell and NK cell count between groups. The study by Veenhof et al. (16) analyzed 42 laparoscopic colectomies. Results showed better CRP levels in patients undergoing laparoscopy alone, while IL-6 and Growth hormone appeared to be better preserved in ERP group, although multivariate analysis did not show differences in $\mathbb{L}-6$

Table 3. Results

\begin{tabular}{|c|c|c|c|c|}
\hline Author & IL-6 & CRP & Pre-albumin & Others \\
\hline Veenhof et al. (16) & $\downarrow$ & $=$ & - & $\mathrm{GH} \downarrow *$ \\
\hline Wang et al. (18) & $\downarrow *$ & $\downarrow *$ & - & CD 4/CD8 RATIO $\downarrow$ * \\
\hline Xu et al. (19) & - & - & $\uparrow$ & TRF $\uparrow{ }^{*}$ \\
\hline Liu et al. (17) & $\downarrow *$ & $\downarrow \star$ & $\uparrow *$ & - \\
\hline Tang et al. (23) & $\downarrow *$ & $\downarrow *$ & - & WBC $\downarrow *$ \\
\hline Guan et al. (22) & - & $\downarrow \star$ & - & - \\
\hline Taupyk et al. (21) & - & $\downarrow \star$ & - & - \\
\hline Mari et al. (20) & $\downarrow *$ & $\downarrow \star$ & $\uparrow *$ & - \\
\hline
\end{tabular}

Legend: IL-6: interleukin-6; CRP: C reactive protein; GH: growth hormone; TRF: transferrin; WBC: white blood cells. *: statistically significant ( $p<0.05)$ 
between groups. Liu et al. did their analysis on an elderly population (age range 60-80) undergoing gastric surgery. They described better $\Pi-6$ and CRP valueson POD 1, 4 and 7 along with faster decline for 21 patients treated with ERP compared to 21 with a standard of care (17). Mari et al.describedthe largest series of cases (140 patients) equally divided between ERP and standard care. They reported significant lower IL-6 for enhanced patients on POD 1, 3 and 5 along with return to baseline from POD 3 (20). No significant difference was found between groups when cortisol and prolactin were dosed.

Taupyk et al. described a series of 70 patients undergoing laparoscopic colectomy, 31 were treated with an ERP program. They choose CRP as surgical stress marker and described lower values for ERP group on POD 1 (21). Wang et al.did the analysis on 80 patients (40 ERP, 40 standard care). Lower stress response in terms of IL-6 and CRP was described for patients undergoing an enhanced protocol on POD 1, 3 and 5 (18). In the same paper, lymphocyte $\mathrm{T}$ sub populations were counted. CD3 and CD4/CD8 ratio were better preserved in ERP patients but no difference between groups was found for CD4 and CD8 expression.Guan et al. reported a comparative study of fast-track versus conventional surgery in patients undergoing laparoscopic radical cystectomy and ileal conduit diversion (22). Their analysis on 115 patients (60 ERP vs. 55 standard care) reported lower WBC count and CRP on POD 5 and 7 , while no difference wasseen on POD 1 and 3. Tang et al. dosed IL-6, WBC and CRP on 100 patients undergoing laparoscopic adrenalectomy, equally divided between ERP and standard care. Blood samples were taken 2 and 24 hours after surgery. They describe better values for ERP group in terms of CRP and IL-6 on both samples while WBC count was lower for ERP group 24 hours after surgery.

Studies investigating nutritional status showed better outcomes for patients undergoing ERP. Mari et al. (20) described higher prealbumin levels along with return to preoperative values on POD 5. Similar results were described by Liu et al. (17). Pre-albumin was higher in ERP Group on POD 4 and 7 compared to traditional care. In the same paper, better albumin and transferrin levels were described. On POD 7 transferrin, albumin and pre-albumin levels returned to preoperative values. $\mathrm{Xu}$ et al. (19) showed higher albumin, pre-albumin and transferrin levels when laparoscopy is associated with ERP protocol, although multivariate analysis did not show any difference between groups.

\section{Grade of Recommendation (SIGN)}

Summarizing the current evidence in the studies analyzed and using SIGN Revised grading system for recommendations in evidence-based guidelines, grade B of recommendation was given based on: 1 RCT study level $1++$ and 7 RCTs studies level 1+, 1 case $^{-}$ control study level $2+$.

\section{Discussion}

The effect of ERP on the SSR is still unclear and recent meta-analysis $(14,24)$ failed to demonstrate the benefit of single ERP items on stress response. Nevertheless, adherence to ERP improves outcomes in patients undergoing colorectal surgery. Only laparoscopy has been found to independently reduce the stress effect, butthere is a lack of studies investigating the SSR in patients treated with an ERP in a laparoscopic setting. The aim of this review was to collect these evidences in order to meet this need.

The three steps of SSR, endocrine, inflammatory and nutritional, were all investigated in the papers included in this review.

There were no powerful evidences of difference in endocrine response among patients. This could be due to the activation of the hypothalamic-adrenergic axis, which is involved in the hormone release, by individual assets. Dosing hormones as markers of this process therefore may not reflect directly the magnitude of trauma. Moreover, different peaks of hormones secretion make it difficult to schedule a precise assessment of sampling time.

Assessing the nutritional status has become 
mandatory for surgical patients since it directly affects complications and length of stay (25). In the papers investigating nutritional markers, better resultsareshown for ERP patients. Prealbumin, transferrin and albumin levels are higher and this reflects the benefit of ERP. In fact, enhanced protocols include early per os feeding and less starving,that leads to better outcomes. During SSR, liver protein synthesis switches from physiology to production of acute phase proteins.This process is responsible for a substrate deprivation and worse outcomes.

Both higher overall proteins and resumption of physiologic liver protein synthesis were seen in patient undergoing ERP and this is a consequence of a shorter inflammatory status.

The inflammatory phase of SSR has been investigated by all the authors, and lower values of IL- 6 and CRP are reported.CRP is commonly used as a clinical marker, while IL-6 is more expensive and less common. Both of them are good markers of surgical trauma in patients. IL-6 is a pleiotropic protein that plays a role in both innate and acquired immunity. As a direct consequence of tissue trauma, it is synthetized locally and acts as a trigger for liver synthesis of other acute phase proteins, such as CRP. IL-6 is frequently higher in patients with chronic inflammatory disease. Moreover, IL-6 stimulates the synthesis of fibrinogen meaning a part in scar tissue growth.Its central role on inflammation is well known and IL-6 has become a target for the treatment of immune-mediated disease (26). All of these features make IL-6 a good marker for SSR.

In this review, the authors described important evidences in favor of ERP by measuring IL-6, CRP and nutritional markers. This is a key statement that could help clinician understand the effectiveness of enhanced protocols in modulating SSR.To a certain extend an adequate stress response is advantageous for patients. Excessive stress nevertheless can lead to a pathological state. Therefore, an attenuated inflammatory response leads to a faster recovery and minimizes the impact of treatment which is advisable, for instance, in older and oncologic patients who are vulnerable to immuno- depression and complications deriving from an uncontrolled stress response.

The next step and future research in perioperative treatment should concentrate on analyzing long term outcomes for enhanced patients, with emphasis on oncologic patients. Benefits of an attenuated SSR could be the key to minimize immunodepression and be a protective feature. Initial studies describe benefits of ERP in terms of long term survival for cancer patients (27).

To the best of our knowledge, this is the first review of studies about ERP and SSR mediators' analysis in a laparoscopic setting. An important limitation of this review is that the majority of the studies are underpowered. The only study providing a sample size calculation tailored on SSR measurement is the one by Mari et al. (20). Veenhof et al. extracted data from the LAFA trial (28), Xu et alfrom FTMDT trial (29). Other trials did not refer as primary end point the difference in surgical stress response between groups. In the study of Mari et al. (20) a significant difference in IL-6 between ERP and standard laparoscopic colorectal surgery was the primary end point. This is also the study that recruited the largest population.

Another limitation is given by the heterogeneous time of sampling of the SSR mediators, which makes comparison of results less reliable.

\section{Conclusions}

ERP applied to different types of laparoscopic surgery has a role in reducing SSR. This can be shown by the analysis of stress mediators such as IL-6, CRP and nutritional markers.

\section{Conflicts of Interest}

All authors certify that all affiliations with or financial involvement in, within the past 5 years and foreseeable future, any organization or entity with a financial interest in or financial conflict with the subject matter or materials discussed in the manuscript are completely disclosed (e.g., employment, consultancies, 
honoraria, stock ownership or options, expert testimony, grants or patents received or pending, royalties).

\section{Author's Contributions}

All authors contributed equally to the manuscript.

\section{References}

1. Gustafsson UO, Scott MJ, Schwenk W, Demartines N, Roulin D, Francis N, et al. Guidelines for perioperative care in elective colonic surgery: Enhanced Recovery After Surgery (ERAS(®)) Society recommendations. World J Surg. 2013;37(2):259-84.

2. Nygren J, Thacker J, Carli F, Fearon KC, Norderval S, Lobo DN, et al. Guidelines for perioperative care in elective rectal/pelvic surgery: Enhanced Recovery After Surgery (ERAS $\circledast$ ) Society recommendations. Clin Nutr. 2012;31(6):801-16.

3. Mortensen K, Nilsson M, Slim K, Schäfer M, Mariette C, Braga M, et al. Consensus guidelines for enhanced recovery after gastrectomy: Enhanced Recovery After Surgery (ERAS $®$ ) Society recommendations. Br J Surg. 2014;101(10):1209-29.

4. Lassen K, Coolsen MM, Slim K, Carli F, de Aguilar-Nascimento JE, Schäfer M, et al. Guidelines for perioperative care for pancreaticoduodenectomy: Enhanced Recovery After Surgery (ERAS $尺$ ) Society recommendations. Clin Nutr. 2012;31(6):817-30.

5. Nelson G, Altman AD, Nick A, Meyer LA, Ramirez PT, Achtari C, et al. Guidelines for pre- and intra-operative care in gynecologic/ oncology surgery: Enhanced Recovery After Surgery (ERAS $($ ) Society recommendations--Part I. Gynecol Oncol. 2016;140(2): 313-22.

6. Thorell A, MacCormick AD, Awad S, Reynolds N, Roulin D, Demartines $\mathrm{N}$, et al. Guidelines for Perioperative Care in Bariatric Surgery: Enhanced Recovery After Surgery (ERAS) Society Recommendations. World J Surg. 2016;40(9):2065-83.

7. Melloul E, Hübner M, Scott M, Snowden C, Prentis J, Dejong CH, et al. Guidelines for Perioperative Care for Liver Surgery: Enhanced Recovery After Surgery (ERAS) Society Recommendations. World J Surg. 2016;40(10):2425-40.

8. Cerantola $Y$, Valerio M, Persson B, Jichlinski P, Ljungqvist 0 , Hubner $\mathrm{M}$, et al. Guidelines for perioperative care after radical cystectomy for bladder cancer: Enhanced Recovery After Surgery (ERAS(®)) society recommendations. Clin Nutr. 2013;32(6):879-87.

9. Lee L, Feldman LS. Improving Surgical Value and Culture Through Enhanced Recovery Programs. JAMA Surg. 2017;152(3):299-300.

10. Kehlet $\mathrm{H}$, Binder $\mathrm{C}$. Adrenocortical function and clinical course during and after surgery in unsupplemented glucocorticoid-treated patients. Br J Anaesth. 1973;45(10):1043-8.

11. McSorley ST, Horgan PG, McMillan DC. The impact of preoperative corticosteroids on the systemic inflammatory response and postoperative complications following surgery for gastrointestinal cancer: A systematic review and meta-analysis. Crit Rev Oncol Hematol. 2016;101:139-50.

12. Watt $D G$, Horgan $P G$, McMillan DC. Routine clinical markers of the magnitude of the systemic inflammatory response after elective operation: a systematic review. Surgery. 2015;157(2):362-80.

13. Artinyan A, Orcutt ST, Anaya DA, Richardson P, Chen GJ, Berger DH. Infectious postoperative complications decrease long-term survival in patients undergoing curative surgery for colorectal cancer: a study of
12,075 patients. Ann Surg. 2015;261(3):497-505.

14. Watt DG, McSorley ST, Horgan PG, McMillan DC. Enhanced Recovery After Surgery: Which Components, If Any, Impact on The Systemic Inflammatory Response Following Colorectal Surgery?: A Systematic Review. Medicine (Baltimore). 2015;94(36):e1286.

15. Moher D, Liberati A, Tetzlaff J, Altman DG; PRISMA Group. Preferred reporting items for systematic reviews and meta-analyses: the PRISMA statement. J Clin Epidemiol. 2009;62(10):1006-12.

16. Veenhof $A A$, Vlug MS, van der Pas MH, Sietses $C$, van der Peet $D L$, de Lange-de Klerk ES, et al. Surgical stress response and postoperative immune function after laparoscopy or open surgery with fast track or standard perioperative care: a randomized trial. Ann Surg. 2012;255(2):216-21.

17. Liu G, Jian F, Wang $X$, Chen L. Fast-track surgery protocol in elderly patients undergoing laparoscopic radical gastrectomy for gastric cancer: a randomized controlled trial. Onco Targets Ther. 2016;9: 3345-51.

18. Wang G, Jiang Z, Zhao K, Li G, Liu F, Pan H, et al. Immunologic response after laparoscopic colon cancer operation within an enhanced recovery program. J Gastrointest Surg. 2012;16(7): 1379-88.

19. Xu D, Li J, Song Y, Zhou J, Sun F, Wang J, et al. Laparoscopic surgery contributes more to nutritional and immunologic recovery than fast-track care in colorectal cancer. World J Surg Oncol. 2015; 13:18.

20. Mari G, Crippa J, Costanzi A, Mazzola M, Rossi M, Maggioni D. ERAS Protocol Reduces IL-6 Secretion in Colorectal Laparoscopic Surgery: Results From a Randomized Clinical Trial. Surg Laparosc Endosc Percutan Tech. 2016;26(6):444-448.

21. Taupyk Y, Cao X, Zhao Y, Wang C, Wang Q. Fast-track laparoscopic surgery: A better option for treating colorectal cancer than conventional laparoscopic surgery. Oncol Lett. 2015;10(1):443-448.

22. Guan X, Liu L, Lei X, Zu X, Li Y, Chen M, et al. A comparative study of fast-track versus (corrected) conventional surgery in patients undergoing laparoscopic radical cystectomy and ileal conduit diversion: Chinese experience. Sci Rep. 2014;4:6820.

23. Tang C, Xu Z, Yi X, Li P, He H, Zhang Z, et al. Fast track surgery vs. conventional management in the perioperative care of retroperitoneal laparoscopic adrenalectomy. Int J Clin Exp Med. 2015;8(9):16207-14. eCollection 2015.

24. Nicholson A, Lowe MC, Parker J, Lewis SR, Alderson P, Smith AF. Systematic review and meta-analysis of enhanced recovery programmes in surgical patients. Br J Surg. 2014;101(3):172-88.

25. Jeejeebhoy KN, Keller H, Gramlich L, Allard JP, Laporte M, Duerksen $\mathrm{DR}$, et al. Nutritional assessment: comparison of clinical assessment and objective variables for the prediction of length of hospital stay and readmission. Am J Clin Nutr. 2015;101(5):956-65.

26. Tanaka T, Narazaki M, Kishimoto T. IL-6 in inflammation, immunity, and disease. Cold Spring Harb Perspect Biol. 2014;6(10):a016295. doi: 10.1101/cshperspect.a016295.

27. Gustafsson UO, Oppelstrup $H$, Thorell A, Nygren J, Ljungqvist 0. Adherence to the ERAS protocol is Associated with 5-Year Survival After Colorectal Cancer Surgery: A Retrospective Cohort Study. World J Surg. 2016;40(7):1741-7. doi: 10.1007/s00268-016-3460-y.

28. Vlug MS, Wind J, Hollmann MW, Ubbink DT, Cense HA, Engel AF, et al. Laparoscopy in combination with fast track multimodal management is the best perioperative strategy in patients undergoing colonic surgery: a randomized clinical trial (LAFA-study). Ann Surg. 2011;254(6):868-75.

29. Zhou JJ, Li J, Ying XJ, Song YM, Chen R, Chen G, et al. Fast track multi-discipline treatment (FTMDT trial) versus conventional treatment in colorectal cancer--the design of a prospective randomized controlled study. BMC Cancer. 2011;11:494. 